\title{
小児における下肢広範囲皮膚欠損に対する治療経験
}

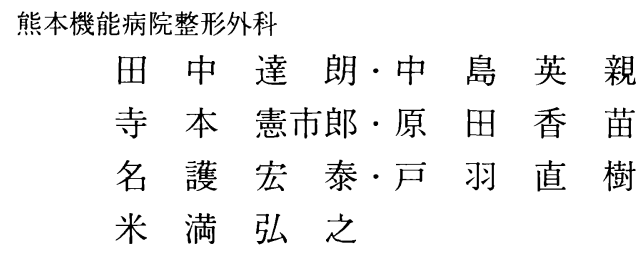

\section{Vascularized Skin Flaps for Coverage of Skin Defects of Lower Extremities in Children}

\author{
Tatsuro Tanaka, Hidechika Nakashima, Kenichiro Teramoto, \\ Kanae Harada, Hiroyasu Nago, Naoki Toba, \\ and Hiroyuki Yonemitsu \\ Department of Orthopedic Surgery, \\ Kumamoto Kinoh Hospital
}

We report cases who underwent vascularized flaps for dermal soft tissue defects of the lower extremities in children. Subjects were patients treated at our department during the past 15 years. They consisted of 10 boys and 2 girls aged 3 to 15 years, with an average age of 8.1 years.

A total of 12 flaps, 3 scapular flaps, and 9 peroneal vascular island reverse flaps were transfered. All flaps survived.

The vascularized flap proved better than free skin graft. Because it grows as the child grows older, ulcers rarely occur. Peroneal vascular island flaps are safe and able to cover massive skin defects without causing microvascular anastomoses. Scapular flaps as free flaps of ten numerous advantages including increased safety and ability without vascular anatomical variation. These results suggest that the vascularized flap is useful for the coverage of skin defects in children.

Key words : Skin graft (植皮), Scapular flap (肩甲皮弁), Peroneal flap (下腿外側皮弁), Skin defect of the leg（下腿皮䖉欠損）

\section{はじめに}

下肢は外傷を受ける頻度が高く，骨および軟部組織 の広範囲損傷を伴うことが多い. 特に, 皮䖉欠損が深 達性で骨や腱などの深部組織の露出を伴う場合には皮 弁による再建術が必要となることが多い。また，小児 においてはこれらの治療に非常に難渋する. 今回, 我々 は 15 歳以下の小児の下肢広範囲皮虐欠損に対し，有 茎 peroneal flap およびScapular flap にて再建し
た症例について検討したので報告する.

\section{対象および方法}

昭和 61 年より平成 12 年までの 15 年間に, 有茎 peroneal flap およびScapular flap にて再建治療 した 15 歳以下の小児 12 例（男 10 例，女 2 例）を対 象とした。患者の手術時平均年齢は 8.1 歳（ $3 \sim 15$

歳）で, 経過観察期間は平均 4 年 6 ケ月（1〜11 年) であった，受傷原因は run over injury などの外傷 
に伴うもの 10 例，脊椎披裂 1 例，放射線潰瘍 1 例で あった。

手術法として Scapular flap を 3 例に, 逆行性の 有菱 peroneal flap 9 例に施行した。これらの症 例について手術部位, 皮弁の種類, 治療成績等を調査 した。

\section{結果}

手術部位は，足背一足関節に9 例うち有茎 peroneal flap 7 例, Scapular flap 2 例，足底に 3 例うち有茎 peroneal flap 2 例, Scapular flap 1 例を施行した。皮弁の大きさは有茎 peroneal flap で平均 $13 \times 4 \mathrm{~cm}(9 \times 3 \sim 20 \times 7 \mathrm{~cm})$, Scapular flap で平均 $14.5 \times 5.5 \mathrm{~cm}(12 \times 4.5 \sim 15 \times 7 \mathrm{~cm})$ と 比較的大きな flap を採取可能であった.

有茎 peroneal flap 9 例はすべて逆行性皮弁とし て用い, run over injuryに伴う足背の皮䖉再建例
が 5 例と最も多く, 最大 $20 \times 7 \mathrm{~cm}$ の皮弁採取が可能

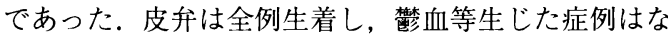
かった。また，Donor siteは緊張の強い症例では一 期的に縫縮せず，PVFをあて，後日植皮することな く一次縫縮を行った（表 1 ）.

Scapular flap は最少年齢 6 歳に施行し, 最大 $15 \times 7 \mathrm{~cm}$ の皮弁採取可能であった．皮弁は全例生着

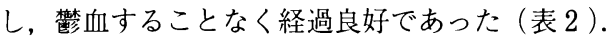

症例

症例 $1: 8$ 歳, 男児

歩行中に車のタイヤにひかれ受傷．当日，PVFを あて 2 週後有茎 peroneal flap 施行した。皮弁はき れいに生着し，足関節の拘縮等なく歩行も正常である. 歩行時痛もなかった（図 1 )。

症例 $2: 6$ 歳, 男児

歩行中にトラックにひかれ受傷. 当日，PVFをあ

表 1 有茎 Peroneal flap 施行症例（15 歳以下）

有茎 Peroneal flap

\begin{tabular}{|c|c|c|c|c|c|c|c|}
\hline No. & 年齢 & 性別 & 受傷部位 & 原因 & 皮弁の大きさ (CM) & 順行/逆行 & 結果 \\
\hline 1 & 3 & 男 & 足背 & run over injury & $3 \times 12$ & 逆行 & 生着 \\
\hline 2 & 6 & 男 & 足背 & run over injury & $4.5 \times 12$ & 逆行 & 生着 \\
\hline 3 & 6 & 男 & 足背 & run over injury & $3.5 \times 9$ & 逆行 & 生着 \\
\hline 4 & 7 & 女 & 踵部 & 脊椎披裂による潰瘍 & $3 \times 6$ & 逆行 & 生着 \\
\hline 5 & 8 & 男 & 足背 & run over injury & $3 \times 12$ & 逆行 & 生着 \\
\hline 6 & 8 & 男 & 下腿 & 開放骨折 · 皮虐欠損 & $3 \times 9$ & 逆行 & 生着 \\
\hline 7 & 8 & 女 & 足背～足関節 & run over injury & $4 \times 24$ & 逆行 & 生着 \\
\hline 8 & 13 & 男 & 足背 & 開放骨折 - 皮虐欠損 & $5 \times 13$ & 逆行 & 生着 \\
\hline 9 & 15 & 男 & 踵部 & 放射線潰痬 & $7 \times 20$ & 逆行 & 生着 \\
\hline 平均 & 8.2 & & & & $4 \times 13$ & & \\
\hline
\end{tabular}

表 2 Scapular flap 施行症例（15歳以下）

Scapular flap

\begin{tabular}{c|c|c|c|c|c|c}
\hline \hline No. & 年齢 & 性別 & 受傷部位 & 原因 & 皮弁の大きさ $(\mathrm{CM})$ & 結果 \\
\hline 1 & 6 & 男 & 足背 & run over injury & $3 \times 9$ & 生着 \\
\hline 2 & 10 & 男 & 踵部 & $\begin{array}{c}\text { 外傷 } \\
\text { (植皮後潰瘍 })\end{array}$ & $15 \times 7$ & 生着 \\
\hline 3 & 9 & 男 & 足関節 足背 & run over injury & $17 \times 5.5$ & 生着 \\
\hline \hline 平均 & 8 & & & & $14.5 \times 5.5$ & \\
\hline
\end{tabular}




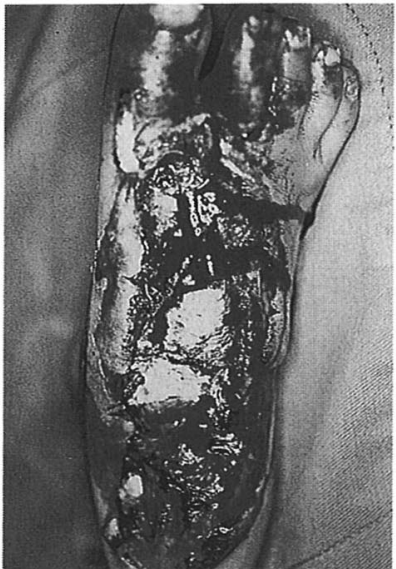

受傷時

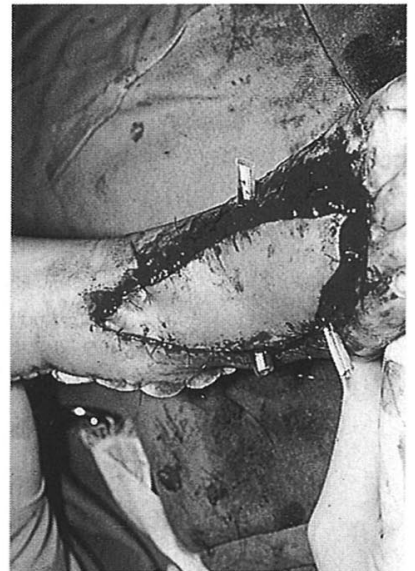

手術時

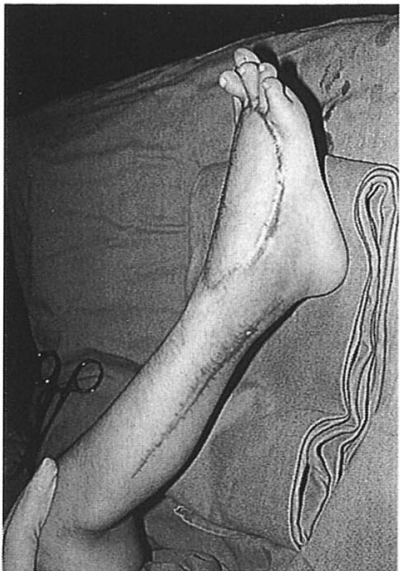

6 ケ月後

図18歳 男児 足背皮膚欠損に対し有茎 Peroneal flap 施行

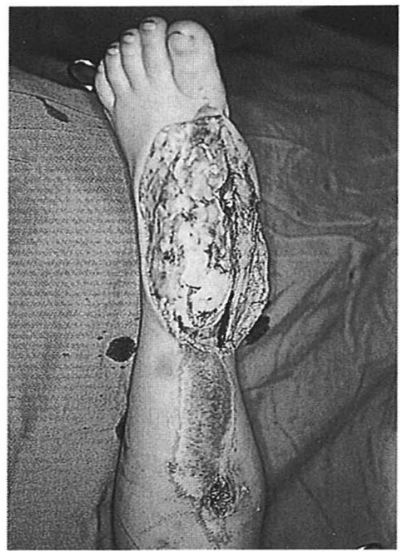

受傷時

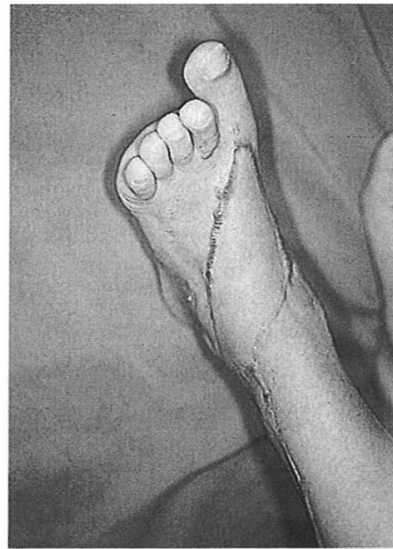

6 ケ月後

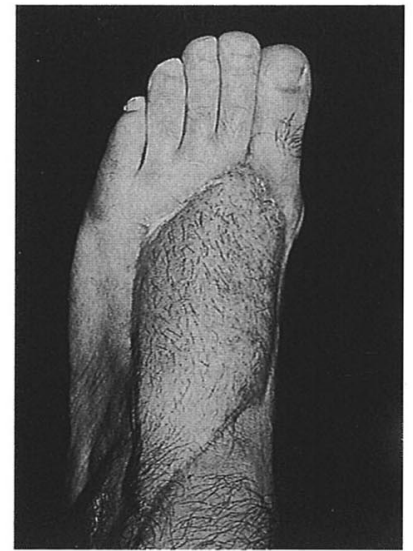

10 年後

図 26 歳 男児 足背皮䖉欠損に対し有茎 Peroneal flap 施行

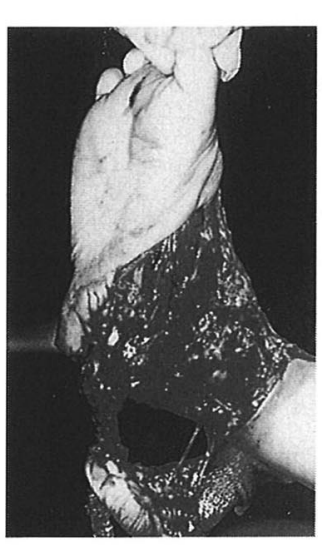

受傷時

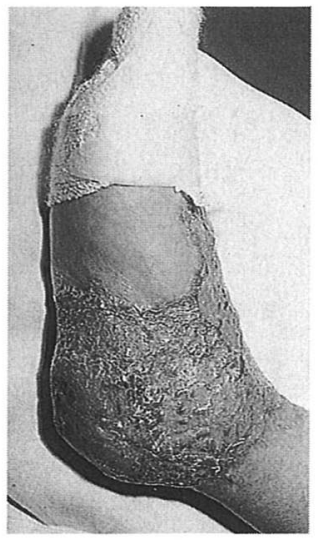

他医で中閒層植皮

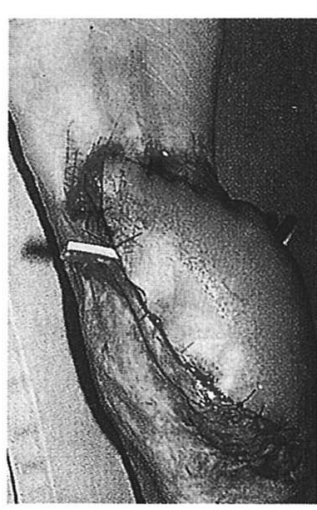

手術時

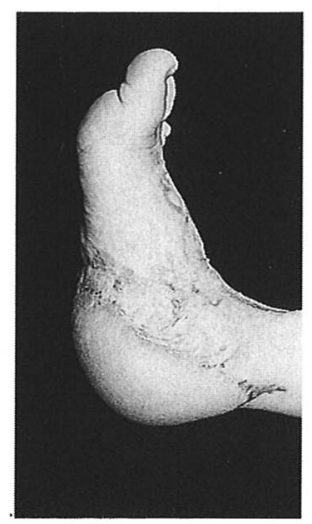

術後 6 力月

図310 歳 男览 踵部の皮膚潰瘍に対しScapular flap 施行 


\section{小児の下肢における広範囲皮膚欠損は治療に難渋する。}

遊離植皮

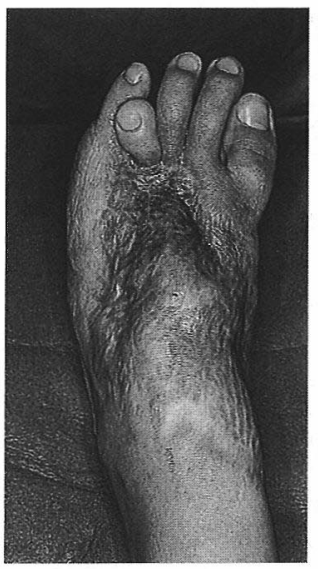

・皮膚のひきつれ

・皮膚の可動性の 欠乏

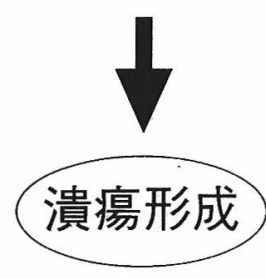

flap

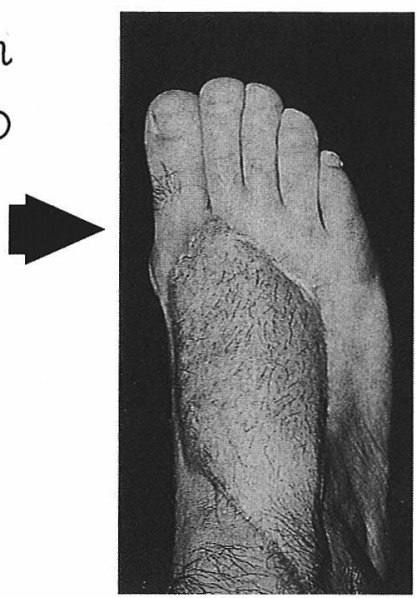

皮下脂肪の存 在により潰瘍 形成の防止

図 4 皮弁の選択

小児においいて vascularized flapによる再建が望ましいと考えられた。

て 2 週後有茎 peroneal flap 施行. 10 年後，皮弁は bulky でなく，潰湯形成等も生じず皮弁の成長も良 好である（図 2 ).

症例 $3: 10$ 歳, 男児

ローラーに巻き込まれ受傷. 踵部の皮䖉欠損を認め, 他医にて中間層植皮施行. しかし, 植皮部の頻回の潰 瘍形成を生じるため当科受診、踵部を Scapular flapにて覆った．皮弁により良好な heel padを作 成し, 以後潰瘍形成は消失した（図 3 ).

\section{考察}

下肢の広範囲皮膚欠損や骨・腱の露出した症例は治 療に難渋することが多い. 特に, 小児においては皮膚 が少なく，また成長過程であるために様々な皮虐障害 が生じてくる，遊離植皮が可能であったとしても皮膚 のひきつれ，皮膚の可動性の欠乏などにより，潰瘍形 成を頻回に生じることが多い。このため, 我々は有荎 peroneal flap およびScapular flap を用いること でこれらの問題点を解決することができた（図 4 ).

有茎 peroneal flap の利点として, 1 ) $5 \sim 6$ 歳以
下の小児にとって血管吻合を必要とせず確実で安全で あり，足趾付近まで移動可能である．2）小児では移 植皮弁も成長するので将来生じるであろう様々な皮䖉 障害が少ない. 3 ）皮弁が薄く, bulky とならない.

4 ) 同一手術野から皮弁が採取でき, 主幹動脈を犠牲 にしない.など大変有用な flapである。

有茎 peroneal flapの欠点としては 1) 術前, 動 脈皮枝の走行，高位などを確実に把握するのが難しい． 2 ）皮弁の移動部位に制限がある。３）逆行性皮弁と いう非生理的状態としたときの, 循環障害（静脈潅流

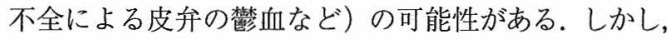
今回我々の症例では, 小児においては皮弁の鬱血は生 じなかった。大人と小児では皮弁の血行動態に差があ るのではないかと考えられた。

一方, Sucapular flapの利点は1）皮弁の血管走 行の解剖学的变異が少ない，2）比較的大きな皮弁が 採取可能である．３）皮弁採取部の創痕がめだたない. 4 ）比較的挙上が容易である。 5 ）小児であっても血 管径が比較的太く, pedicle も長く採取できる. 1982 年 Gilbert ${ }^{1)}$ らは小児において, その皮弁の動脈径は 
0.8 1.2mm である（大人は $1.5 \sim 2.0 \mathrm{~mm}$ ) と述べて いる。実際，我々の症例においても皮弁の動脈径は 1 $\mathrm{mm}$ 前後であった。このため, 比較的容易に血管吻 合も施行できた.

Sucapular flapの欠点としては，1）知覚皮弁と して用いられない．2）やゃbulky な皮弁となるた め defatting が必要となる.1990年 Rautio4)らは皮 下組織の厚さを調べ，前足部で約 $7 \mathrm{~mm}$, 踵部で約 $13.5 \mathrm{~mm}$ であると報告している. Sucapular flapの 厚さが約 7 14.5mm であることを考えると，特に 前足部に使用した場合には defatting が必要となるこ とが多い.

最後に，小児における flapの特徴として，1）皮 弁は身体の成長とともに成長するため, 瘏痕等生来生 じるであろう皮膚障害が少ない．2）小児の血管は動 脈硬化等がなく，柔軟性が良いため皮弁が生着しやす い。などがあげられる。今回，我々の症例に抢いて flap 施行後潰瘍形成を生じた症例はなかった。

また, Sucapular flapは知覚皮弁として用いられ ないという欠点があるが, 知覚再建しない皮弁でも年 月とともに知覚が回復するという意見もある。1986 年 $\mathrm{Chang}^{1)}$ は知覚再建を行わない皮弁でも spontaneous neurotization が長期には認められ，筋弁に 分層植皮を行ったものでは組織学的に神経終末が認め られない, 筋弁は皮弁に劣ると述べており，1989 年 Lahteenmaki ${ }^{2)}$ も健常な組織上に強固に縫合された 皮島を有する遊離皮弁は神経縫合なしに表面圧覚, 温 度覚の一部を得る可能性があると主張している。また，
1994 年高松ら ${ }^{51}$ は, Sucapular flapを施行した 10 例中 7 例に知覚回復があったと報告している，我々の 症例では, 2 例に若干の圧覚を認めたがはっきりはし なかった. flapの知覚回復に関しては, 今後の研究 の成果が待たれるところである.

$$
\text { ま と め }
$$

(1) 小児の下肢広範囲皮膚欠損に対し, Sucapular flap を 3 例, 有茎 peroneal flap 9 例に施行し, 全例生着した。

(2) 小児にとって有茎 peroneal flap は血管縫合を 必要とせず安全である。

(3) 損傷の状態で有茎 peroneal flap が使用できな いとき, 血管径が大きく, 血管の解剖学的異常が少な いSucapular flapが大変有用であった.

\section{参考文献}

1) Chang, K. N, DeArmond, S. J., Buncke, H. J.: Sensory reinnervation in microsurgical reconstruction of the heel. Plast. Reconstr. Surg., $78: 652-663,1986$.

2) Lahteenmaki, $T$. et al.: Recovery of sensation in free flaps. Scand J Plast Surg., 23 : 217-222, 1989.

3) Gilbert. A., Teot, L.: The free scapular flap. Plast. Reconstr. Surg., 69 : 601-604, 1982.

4) Rautio, J. et al.: Suitability of the scapular flap for reconstruction of the foot. Plast. Reconstr. Surg., $85:$ 922-928, 1990.

5）高松严子, 他：遊離肩甲皮弁による足底再建の長期経 過観察. 形成外科, 37(10): 1137-1144, 1994. 